\title{
Adopting Strategic Management Approach in the Capital Market Development: The Nigerian Case
}

\author{
Augustine, UJUNWA, Ph.D (Corresponding author) \\ Department of Banking and Finance, University of Nigeria, Enugu Campus \\ Tel: 234-803-501-0116_E-mail: austinesilver@yahoo.com \\ Nwanneka Judith, MODEBE \\ Department of Banking and Finance, University of Nigeria, Enugu Campus \\ Tel: 234-703-066-2470
}

Received: July 25, 2011

doi:10.5539/ijef.v4n1p223

\author{
Accepted: September 6, 2011 \\ Published: January 1, 2012 \\ URL: http://dx.doi.org/10.5539/ijef.v4n1p223
}

\begin{abstract}
This paper examines the roles and channels through which the capital market promotes economic development. The paper documents extensive evidence to show the adverse effects of the recent global financial crisis on the Nigerian capital market. Given the pivotal role of the capital market in economic development, the study advocates for the adoption of strategic management approach in ensuring capital market efficiency. These strategic management measure ranges from effective regulation to achieving favourable macroeconomic environment. These strategies will not only promote the efficiency of the capital market, but will leverage the role of the capital market in promoting economic growth.
\end{abstract}

Keywords: Capital Market, Economic development, Strategic management

\section{Introduction}

Improving the efficiency of the capital market has become a recognized means of meeting national objectives such as enhancing productivity and competitiveness, reducing local environmental costs associated with capital market transactions, promoting savings and investment on economic wide basis (Mark, 2011). At international level, it is considered a key element of strategy to mitigate the risk of capital flight associated with lack of international investors' confidence in the market. In this context, improving capital market efficiency in the developing and transitioning countries is particularly important because these countries exhibit considerable potential for such improvement and, in the case of the developing countries, since they will contribute increasingly to the future of the capital market as their economies grow (Ujunwa and Salami, 2010).

In Nigeria, the strategies for improving capital market efficiency, given the recent scandals in the entire corporate governance spectrum has elicited serious interest among scholars and practitioners. Practitioners have advocated for capital market transformation programme. Definitions of what constitutes capital market transformation programme vary somewhat, but the general consensus is that such programme "explicitly seek to cause changes in the structure of the market for product or service, or in the behavior of some group of market actors, in such a way that market efficiency is improved and the changes remain after the programme has ended" (Momoh, 2007). The key element of the capital market transformation is the application of strategic management in capital market theories.

Integrating the links between strategic management and capital market has received little attention among practitioners and scholars. This might be based on the myth that strategic management and capital market theories belong to two different disciplines. Strategic management belongs to the field of business management, while capital market theories belong to the field of traditional finance.

Strategic management is an important aspect of management that elicits research interest among scholars and practitioners. This can be attributed to the universal application of this aspect of management discipline. Strategic management is generally seen as the art and science of formulating, implementing, and evaluating cross-functional decisions that enables an organization to achieve its objectives (David, 2008). Essentially, it focuses on integrating management, marketing, finance and accounting, production and operations, research and developments, and 
computer information system in achieving organisational objectives. Ituwe (2004), identifies the three stages of strategic management as strategy formulation, strategy implementation and strategy evaluation.

The capital market, on the other hand, is a collection of financial institutions set up for the mobilization and utilization of long-term funds for developing the long-term end of the financial system (Ologunge; Elumilade and Asaolu, 2006). In this market, lenders (investors) provide long-term funds in exchange for long-term financial assets offered by issuers. The market is an important institution for capitalist countries because it encourages investment in corporate securities, providing capital for new businesses and income for investors (Ujunwa, 2008). How can we use these two (strategic management and capital market) to achieve capital market efficiency?

This paper provides answers to the above question by suggesting strategic management options that can be adopted to ensure market efficiency, and restore investors' confidence. The rest of the paper is divided as follows; Following the introduction is section 2 which $x$-rays the role of capital market in the economy. Section 3 suggests strategies for promoting capital market efficiency in Nigeria and section 4 concludes the paper.

\section{Capital Market and the Economy}

The capital market is one of the most vital areas of the economy as it provides companies access to capital, and investors with a slice of ownership in the company and the potential of gains based on the company's future performance. Okafor (1983) categorizes the market in three ways; on the basis of securities exchanged (bond and equity stock market); on the basis of market organization (security exchange and over- the counter stock market); on the basis of age (primary and secondary Market). He further subdivided the bond market into corporate bond market, the municipal bond market and the market for government bonds. The market is generally classified into two main sections; the primary and the secondary market. The primary market is where new issues are first offered (new issue market), with any subsequent trading going on in the secondary market (stock market). The instruments tradable in the capital market are bonds, government development stocks, industrial loans, preference stocks, and equities (Nigerian Stock Exchange Fact Book, 2005 and 2006).

The capital market is unique in a country's financial system because of its peculiar role in the economy. Levine (1991) identified these roles as: raising capital for business, mobilizing savings for investment, facilitating company's growth, redistribution of wealth, promotion of corporate governance, creating investment opportunities for small investors, government capital raising avenue for development projects and being a barometer of the economy.

As the major source of appropriate long-term funds, the capital market is obviously crucial to any nation's economic development. Specifically, the capital market facilitates economic growth by, among other things, mobilizing savings from numerous economic units such as governments, individuals and institutional investors for users such as governments and the private sector. It also improves the efficiency of capital allocation through a competitive pricing mechanism. Specifically, the capital market plays the following roles in the economy;

\subsection{Raising Capital for Businesses}

The capital market is unique and different from banks because; it provides companies with the facilities to raise capital for expansion through selling of shares to the investing public (Levine, 1991). Firms raise bonds and equity through the new issue segment of the capital market. This helps in easing the financing constraints of firms, and equity most importantly becomes a permanent capital, which enhance the production capacity of firms in a country. Companies view acquisitions as an opportunity to expand product lines, increase distribution channels, hedge against volatility, increase its market share, or acquire other necessary business assets. A takeover bid or a merger agreement through the capital market is one of the simplest and most common ways for a company to grow by acquisition or fusion (Yartey, 2006).

\subsection{Savings Mobilizing}

The capital market facilitate saving mobilization. Transactions cost and asymmetric information (adverse selection and moral hazard) make the mobilization of savings costly. For example, in the presence of asymmetric information, risk-averse agents do not feel comfortable entrusting their savings to others. Because transactions and information costs are associated with collecting saving from many disparate agents, Capital markets emerge to ameliorate these frictions and ease savings mobilization (King and Levine, 1993a, b). Capital markets that are more effective at pooling or mobilizing savings from several agents can have strong positive effects on economic development by boosting capital formation and improving resource allocation.

\subsection{Information Acquisition and Resource Control}

It is costly and difficult to evaluate firms, managers, and market conditions. Savers shy away from investment activities where they have unreliable information, which may negatively affect resource allocation. Instead of having 
each potential investor seeking and paying for information, the capital market can do that. It is argue that since many firms and entrepreneurs will solicit capital, markets that are better at selecting the most promising firms and managers will induce a more efficient allocation of capital and therefore foster growth.

Capital markets may also have a positive effect on financial markets, since it is easier for an agent who acquired information to disguise this private information and profit from it (Ujunwa, 2008). Therefore, large liquid stock markets may stimulate the acquisition of information, which in turn could improve resource allocation and hence growth.

\subsection{Management Monitoring and Corporate Control}

Capital markets may promote corporate control. For instance, if public trading of shares in capital markets properly reflects information about firms then owners can link managerial compensation to stock prices (Levine and Zervos, 1996). This helps align manager's interest with those of owners, Furthermore, if takeovers are easier in a well-developed capital market and if managers of under-performing firms are fired following takeovers, then better capital markets can promote better corporate control by easing take-over of poorly managed firms. The threat of takeovers helps align managerial incentives with those of the owners.

\subsection{Corporate Governance}

By having a wide and varied scope of owners, companies generally tend to improve on their management standards and efficiency in order to satisfy the demands of these shareholders and the more stringent rules for public corporations imposed by public stock exchanges, and the government. Consequently, it is alleged that public companies (companies that are owned by shareholders who are members of the general public and trade shares on public exchanges) tends to have better management records than privately-held companies (those companies where shares are not publicly traded, often owned by the company founders and/or their families and heirs, or otherwise by a small group of investors). However, some well-documented cases are known where it is alleged that there has been considerable slippage in corporate governance on the part of some public companies (Levine, 1991).

\subsection{Government Capital Raising for Development Projects}

Governments at various levels may decide to borrow money in order to finance infrastructure projects such as sewage and water treatment plants or housing estates by selling another category of securities known as bonds. These bonds can be raised through the Stock Exchange whereby members of the public buy them, thus loaning money to the government. The issuance of such municipal bonds can obviate the need to directly tax the citizens in order to finance development, although by securing such bonds with the full faith and credit of the government instead of with collateral, the result is that the government must tax the citizens or otherwise raise additional funds to make any regular coupon payments and refund the principal when the bonds mature (Felagan, 1987). A good case was the decision of the Federal Government of Nigeria to use the capital market in financing its development plans in the 1960s, 1980s, 1990s and even recently (CBN, 2004).

\section{Strategies for an Efficient Capital Market in Nigeria}

A market is generally viewed as efficient when the number of buyers and sellers is sufficiently large, and all participants are small enough relative to the market, so that no individual market agent can influence the price of commodities (Benston, 1973). Efficient capital market however, can be viewed from two perspectives; operational efficiency and pricing efficiency. In an operational efficient market, investors can obtain transaction services as cheaply, given the cost associated with the furnishing of those services. Pricing efficiency refers to a market where prices at all times reflect the market fundamentals that are relevant for the evaluation of securities. This is generally referred to as symmetric information. The efficient market hypothesis postulates that a market can be efficient in the strong form, semi-strong form and weak form depending on the level of development of the market.

Characteristic of efficient capital market is the necessity for efficient information-disclosure procedures, contracting systems, and accounting standards. For example in market-based systems, such as the United States, a substantial number of firms are publicly listed and face extensive disclosure requirements. This implies that a great deal of information is revealed and, as a result, difficulties associated with savings mobilization are lowered.

The Nigerian capital market witnessed unprecedented boom between 2004 and 2008. The market was regarded as one of the fastest emerging capital market in the world, which was evident in the increasing size of its market capitalization. The market capitalization rose from N2.08 trillion in 2005 to N3.51 trillion in 2006, representing 59.3 per cent growth rate (Nigerian Stock Exchange Fact book, 2006). According to Oluseyi (2008), "In 2007, the [Nigerian capital] market was the fourth best performing in the world; in terms of sheer growth. Nigerian's All Share Index came fourth behind China's Shanghai Index (97 per cent growth), PFTS of Ukraine (a fairly new market), and Slovenian Index. With a growth rate of 73 per cent in 2007, and mere fact that she featured 
prominently in the list of best performing stock market in the world, moving from the ninth position as at June 2007 , to finish off at fourth in December 2007".

The global financial crisis of 2008, which crept into the Nigerian capital market impacted negatively on market performance indicators. The Nigerian Stock Exchange that witnessed unprecedented growth in total market capitalization and value of share traded for 2004 to early 2008, is currently experiencing a serious downturn in its activities. According Udeme and Onuba (2009) the market capitalization of the 303 listed equities., which had opened on January $1^{\text {st }}, 2008$, at N10.18tn and later appreciated to N12.395tn as at March 2008, suffered its highest fall in the 48-year history of the Nigerian Stock Exchange, depreciating by N3.223tn or 32 per cent to N6.957tn by the year end. Similarly, the NSE All Share Index depreciated by the same margin from 63,016.60 at which it opened in January, to 31,450.78 at the last trading day at 2008 (Udeme and Onuba, 2009).

This crisis has also revealed poor corporate governance practices among market participants, leading to inefficiency in the market. Investors who lost huge sum of money in the capital market when the bubble burst have developed serious apathy for the capital market. This apathy is heightened by the decision of the government not to bail-out the capital market. In the academic circle, scholars have intensified research effort in discovering other sources of investment aside the capital market. As investors' apathy for the capital for market heightens, and in view of the important role of the capital market to the economy, it becomes imperative to explore strategic management measure that will restore confidence in the market. To attain such desire operational and pricing efficiency, market regulators must adopt the following strategic measures;

\subsection{Pursue Stable Macroeconomic Environment}

The government should pursue earnestly a stable macroeconomic environment. A stable macroeconomic environment is crucial for the development of the capital market. Macroeconomic volatility worsens the problem of informational asymmetries and becomes a source of vulnerability to the financial system. Low and predictable rates of inflation are more likely to contribute to capital market development and economic growth. Both domestic and foreign investors will be unwilling to invest in the capital market where there are expectations of high inflation. Sound macroeconomic environment and sufficiently high income levels-GDP per capita, domestic savings, and domestic investments are determinants of capital market development in emerging markets.

\subsection{Foster Banking Sector Development}

There should be policy measures to foster the development of the Nigerian banking system. The development of the banking sector is important for stock market development in Nigeria. At the early stages of its establishment, the capital market is a complement rather than substitute for the banking sector. Support services from the banking system contribute significantly to the development of capital market. Conversely, a weak-banking system can constrain the development of viable capital market. Most stock market indicators are highly correlated with banking sector development and countries with well-developed capital market tend to have well-developed financial intermediaries.

\subsection{Restoration of Public Confidence}

The most effective strategy to having an efficient capital market is restoring investors' confidence. Public confidence allows activities in the capital market to thrive, since the system will not create room for manipulation. This can be achieved by significantly enhancing the dual role of effective regulatory oversight and capital market development. Oteh (2010) notes that, "these two roles reinforce each other as adequate regulatory oversight fosters a well-functioning capital market".

This entails tackling weak governance and insufficient capacity as witnessed in the market recently. Securities laws and rules must be enforced and strict compliance ensued. The Securities and Exchange Commission must strategically place its Compliance Division to ensure that the decisions of its Management on cases of malpractices in the market as well as its administrative directives are complied with. It is generally argued that "In the absence of enforcement and compliance, rules will be broken with impunity and the Commission will be a toothless bulldog which will lead to the erosion of public confidence".

\subsection{Cost Reduction or Pricing Efficiency}

At the peak of the capital market crisis, the Federal Government of Nigeria (FGN) and all the major stakeholders in the Nigerian Capital market met in Abuja, Nigeria on August 26, 2008 to map out ways forward to stem the sliding fortunes of the Nigerian equity market. One of the strategies adopted was that the Securities and Exchange Commission (SEC), the Nigerian Stock Exchange (NSE), and all Capital Market operators should reduce the burden on investors by cutting fees significantly. The NSE decided to cut its fees by 50 per cent effective August 27, 2008. The thinking is that the strategy will "reduce transaction costs, increase profit margin to investors, make the market 
more competitive with the international market, attractive to foreign investors and increase buying and selling activities". This strategy focused on the secondary segment of the market as if it is the panacea to the recent banking crisis.

There is a need to improve efficiency and cost competitiveness in all aspects of the market as the high transaction cost is a huge deterrent to companies wishing to enter the market. It is also essential to review primary and secondary market issuance costs. The Exchange must ensure that firms submit their financial statements, in order to ensure that the prices of stock reflects market company fundamental. This will also reduce the risk of over pricing of shares and insider trading which is the end product of asymmetric information.

\subsection{Create a Wider Range of Financial Market Instruments}

There is an urgent need to increase the variety of financial instruments trade-able in the exchange. This has the capacity of increasing the depth, breadth and sophistication of the capital market. The Nigerian capital market is dominated with dealings in equity instruments, with the recent resurgence of government development bonds. In developed economies, the capital markets have wider variety of instruments that promote the efficiency of the market. To enhance the efficiency of the Nigerian capital market, we need to expand market offerings to include products such as fixed income securities. Hedging and derivatives instruments such as futures, options, forwards, swaps and exotics need to be promoted as well as securities lending and collective investment schemes.

\subsection{Symmetric Information}

One of the characteristics of efficient capital market is information symmetry. This is a practice where all market participants are equally privilege to information on market condition. This can be achieved through disclosure, transparency and accountability. The absence of effective disclosure, transparency and accountability, undermines the market and creates perverse incentives for those individuals determined to bend the rules (Oteh, 2010). Therefore, the Securities and Exchange Commission must ensure that all public companies disclose meaningful and relevant information to the public. Effective disclosure system thrives with good accounting system. This brings to the fore, the importance for the adoption of the International Financial Reporting Standard in Nigeria. The Securities and Exchange Commission can advance this pursuit using the modern information technology innovation to improve disclosure. A very good example is the giant stride by Central Bank of Nigeria, in data intelligence through data capturing machine.

Information symmetry will offer quality and timely information for decision making, which leads to broader investment opportunities for investors. It also restores international confidence as such disclosure requirements conform to international standard, and also help market regulators to detect deviations from the rules and regulations.

\section{Conclusion}

The Nigerian capital market witnessed unprecedented growth in terms of market capitalisation and all share index between 2004 and the early part of 2008. The market boom is attributable to the banking sector reform, which required that existing banks in Nigeria must shore-up their share capital to N25b or have their licenses revoked. Though the reform strategy was government induced mergers and acquisition, the capital market provided banks another channel to comply with the regulatory requirements.

The 2008 global financial crisis resulted in the mass exodus of foreign investors from the Nigerian capital market. Within the period, the bubble burst and most local investors that relied on the statement of the Central Bank of Nigerian Governor at that time that "the Nigerian capital market is insulated from the crisis because of the low integration of the Nigerian financial system to the global financial markets" were caught in the gap. This resulted in the huge loss of investment. The crisis also revealed unethical practices and high profile fraud going on in the market at that time.

All these culminated into loss of confidence and investors' apathy in the market. This development has propelled scholars to undertake studies, with the aim of identifying alternative investment channels. Given the pivotal role of the market in economic development, it becomes imperative to adopt strategic management measures to ensure the efficiency of the capital market. These measure ranges from effective regulation to achieving favourable macroeconomic environment. These strategies will not only promote the efficiency of the capital market, but will leverage the role of the capital market in promoting economic growth.

\section{References}

Benston, G. J. (1973). Required Disclosure and Stock Market: An Evaluation of the Securities Exchange Act of 1934. American Economic Review, 132-155 
Central Bank of Nigeria. (2004). Financial Markets in Nigeria, Abuja: CBN Publication, (Chapter 6).

David, F.R. (2008). Strategic Management: Concepts and Cases, 7ed, New Delhi: Prentice Hall (Chapter 1). of India

Felagan, B.S. (1987). Redesigning Nigeria's Financial System, Ibadan: University Press Limited, (Chapter 9)

King, R.G, \& Levine, R. (1993a). Finance and Growth: Schumpeter Might Be Right. The Journal of Economics, 108(3): $717-738$

King, R.G, \& Levine; R. (1993b). Finance, Entrepreneurship and Growth. Journal of Monetary Economics, 32: 130. http://dx.doi.org/10.1016/0304-3932(93)90028-E

Ituwe, C.E. (2004). Strategic Management: Theory and Practice, Lagos: Excel Bookhouse, (Chapter 2)

Levine, R, \& Zervos, S. (1996). Stock Market Development and Long-Run Economic Growth. The World Bank Policy Research Paper 582: 1 -27.

Levine, R. (1991). Stock Markets, Growth, and Tax Policy. Journal of Finance, 46(4): 1445-1465. http://dx.doi.org/10.2307/2328866

Mark, J.R. (2011). Capital Markets and Financial Politics: Preferences and Institutions, Oxford Handbook on Capitalism (forthcoming).

Momoh, M.A. (2007). Understanding the Economic Value of the Capital Market, Presentation at a 1-Day Workshop on Taxation and the Capital Market in Nigeria, Organised by the Ogun State Board of Internal Revenue Abeokuta. 2nd August.

Nigerian Stock Exchange Fact Book. (2005).

Nigerian Sock Exchange Fact Book. (2006).

Okafor, F.O. (1983). Investment Decisions: An Evaluation of Projects and Securities, London: Cassell LTD, (Chapter 5).

Ologunde, A.O, Elmilade, D.O, \& Asaolu, T.O. (2006). Stock Market Capitalization and Interest Rate in Nigeria: A Time Series Analysis. The International Research Journal of Finance and Economics, 4: 155-166.

Oluseyi, B. (2008). Averting Financial Crisis in Nigeria, Daily Punch of $13^{\text {th }}$ November 6-7.

Oteh, A. (2010). A Road Map for Transforming the Nigerian Capital Markets, A Press Briefing at SEC Media Centre, Lagos, on th $5^{\text {th }}$ of February.

Udeme, E., \& Onuba, I. (2009). Global Financial Crisis: Keeping the Nigerian Stock Market Viable, Daily Punch of $5^{\text {th }}$ January.

Ujunwa, A., \& Salami, P.O. (2010). Stock Market Development and Long-Run Growth: Evidence from Nigeria. European Journal of Economics, Finance and Administrative Sciences, 25: 44-53.

Ujunwa, A. (2008). Impact of Stock Market Development on Economic Growth: Evidence from Nigeria, M.Sc Dissertation Submitted to the Department of Banking and Finance, University of Nigeria, Enugu Campus.

Yartey, C.A. (2006). Stock Market and the Financing of Corporate Growth in Africa: The Case of Ghana, IMF Working Paper WP/06/201 international Monetary Fund Washington D.C: 1-30. 